\title{
Angiotensin II Directly Stimulates Sodium Transport In Rabbit Proximal Convoluted Tubules
}

\author{
V. L. Schuster, J. P. Kokko, and H. R. Jacobson \\ Department of Internal Medicine, Division of Nephrology, The \\ University of Texas Health Science Center, Southwestern \\ Medical School, Dallas, Texas 75235
}

bstract. Numerous previous studies have proposed a role for angiotensin II (AII) in the renal regulation of salt balance. At least one nephron site, the proximal convoluted segment, has been implicated in this role. We used in vitro microperfusion of rabbit proximal convoluted tubules to further examine this question. To insure use of appropriate in vivo concentrations as well as potency of the hormone in vitro, we measured plasma AII levels by radioimmunoassay in normal, sodium-depleted, and adrenalectomized rabbits, and measured AII activity by bioassay after incubation in various microperfusion baths. Plasma levels ranged from $\sim 2$ $\times 10^{-11}$ to $5 \times 10^{-11} \mathrm{M}$. AII activity was stable in Ringer's solution plus albumin, but not in rabbit serum or Ringer's solution plus fetal calf serum.

In Ringer's solution plus albumin, physiologic concentrations of AII stimulated volume reabsorption $\left(\mathrm{J}_{\mathrm{v}}\right)$. $10^{-11} \mathrm{M}$ AII increased $\mathrm{J}_{\mathrm{v}}$ by $16 \%(P<0.01) \cdot 10^{-10} \mathrm{M}$ AII produced a lesser increase, $7.5 \%(P<0.05)$. At a frequently studied, but probably pharmacologic dose, $10^{-7}$ M AII inhibited $\mathrm{J}_{\mathrm{v}}$ by $24 \%(P<0.001)$. AII at $10^{-11} \mathrm{M}$ did not stimulate $J_{v}$ in the presence of $10^{-7} \mathrm{M}$ saralasin. Though previous studies have suggested agonistic effects of saralasin alone in epithelia, we found no significant effect of $10^{-7} \mathrm{M}$ saralasin on $\mathrm{J}_{\mathrm{v}}$. None of the AII doses measurably changed transepithelial voltage.

These data were presented in part at the National Meeting of the American Federation of Clinical Research, May 1982 and have been published in abstract form in Clin Res. 30:462A, 1982.

Dr. Schuster was a Roche Fellow of the National Kidney Foundation during part of this work. Dr. Jacobson is the recipient of National Institutes of Health Research Career Development Award 1-KO4-AM00537.

Received for publication 9 February 1983 and in revised form 20 September 1983.

J. Clin. Invest.

(c) The American Society for Clinical Investigation, Inc.

0021-9738/84/02/0507/09 $\$ 1.00$

Volume 73, February 1984, 507-515
We conclude that AII in physiologic doses directly stimulates $J_{v}$ in proximal convoluted tubules and this effect is probably receptor mediated and, within the limits of detection, electroneutral.

\section{Introduction}

The role of angiotensin II (AII) ${ }^{1}$ in salt and water homeostasis has been increasingly well described in recent years. In addition to its role in aldosterone synthesis, AII alters the slope of osmolar antidiuretic hormone release (1), produces a central dipsogenic response and salt appetite (1), and enhances salt and water transport by the small intestine $(2,3)$ and colon $(2,4,5)$.

Since the demonstration by Hughes-Jones et al. in 1949 (6) that systemic infusions of a crude renin preparation produced natriuresis, numerous investigators have examined the role of the renin-angiotensin system, and particularly AII, in renal salt and water transport. Clearance studies in several species demonstrated that, in general, systemic infusion of AII at rates $<100$ $\mathrm{ng} \cdot \mathrm{kg}^{-1} \cdot \mathrm{min}^{-1}$ produced antinatriuresis, whereas higher infusion rates produced natriuresis (7). When measured, the filtration fraction rose at all AII infusion rates. Since an increased filtration fraction favors proximal tubular volume reabsorption via peritubular mechanisms, a direct effect of AII on proximal function could not be ascertained by these studies.

Though several micropuncture studies utilizing systemic AII administration found no effect on proximal volume reabsorption (8-10), other studies applying AII directly to the peritubular surface found a biphasic dose response. Steven (11) found inhibition of proximal volume reabsorption when $2 \times 10^{-8} \mathrm{M}$ AII was infused into superficial peritubular capillaries. Spinelli and Walther (12) applied AII to the decapsulated cortical surface and found stimulation of proximal reabsorption at $\sim 10^{-10} \mathrm{M}$, but inhibition at $\sim 10^{-5} \mathrm{M}$. Harris and Young (13), using in vivo microperfusion of both lumen and capillaries, showed maximal stimulation of sodium efflux from the lumen at peritubular concentrations of $10^{-11} \mathrm{M}$, but inhibition at $10^{-6} \mathrm{M}$.

While suggesting a direct effect of AII, these studies leave several questions unanswered. First, only superficial convolutions

1. Abbreviations used in this paper: AII, angiotensin II; CVP, constant volume pipette; $\mathrm{J}_{\mathrm{v}}$, net volume flux; $V_{\mathrm{T}}$, transepithelial voltage. 
were examined. Since deep nephrons differ from superficial ones in a number of ways, including lower single-nephron renin activities (14) and higher volume reabsorptive rates (15), the response of deep nephrons to AII is of interest. Second, renal nerves were presumably intact in the studies cited. Since AII is known to enhance norepinephrine release from sympathetic nerve endings, and since catecholamines per se can influence proximal reabsorption (16), a direct effect of AII on the epithelium cannot be concluded. Third, AII may be vasoconstrictive, particularly at high doses, and thus resistance changes in peritubular capillaries induced during AII infusion have been suggested (17).

The isolated, perfused tubule appears to be an ideal technique by which to examine AII's effect. Deep convolutions are easily accessible, dissected tubules are free of sympathetic nerve endings by electron microscopy (Tisher, C. Craig, personal communication), and transport mechanisms are relatively easily defined. Although one early isolated tubule study found no effect of $10^{-6}$ $M$ bath AII on proximal volume reabsorption (18), we have reexamined AII effects using this technique and have found a direct, biphasic dose response of AII on proximal volume reabsorption.

\section{Methods}

AII radioimmunoassay (RIA) and plasma levels. AII concentration was measured in plasma using an RIA developed by Arant and Stephenson (19). This assay has a lower limit sensitivity of $\sim 3 \mathrm{pg} / \mathrm{ml}$ and a crossreactivity with AII of $\sim 60 \%$. Plasma levels were measured in three groups of rabbits: (a) normal rabbits on standard laboratory chow (Wayne Feeds; Chicago, IL) and tap water, who gained an average of $0.26 \pm 0.03$ $\mathrm{kg} / \mathrm{wk},(b)$ normal rabbits given furosemide, $2.0 \mathrm{mg} / \mathrm{kg}$ s.c. body weight, followed by $7 \mathrm{~d}$ of a zero-sodium diet (ICN Nutritional Biochemicals, Cleveland, $\mathrm{OH}$ ) and distilled water, during which time the mean weight loss was $0.11 \pm 0.06 \mathrm{~kg}$, and $(c)$ rabbits $7-14 \mathrm{~d}$ postadrenalectomy (20) fed normal rabbit chow and $0.9 \%$ saline for drinking water. At decapitation, free-flowing mixed arteriovenous blood was collected in chilled heparin-containing beakers, centrifuged, and the plasma immediately placed in tubes containing $250 \mathrm{mM} \mathrm{1,10}$ ortho-phenanthroline and 125 MM EDTA for RIA.

AII bioassay and stability in tubule baths. To determine stability of synthetic AII in various standard isolated tubule baths, a bioassay for AII was used (21). Briefly, rat stomach and colon strips were mounted on tension transducers and superfused with oxygenated Ringer's solution. Spontaneous muscular activity was abolished with a variety of neuromuscular blockers (21), and contractile responses to 1 and $10 \mathrm{ng} 5$-ileAII (Beckman Instruments, Inc., Palo Alto, CA) were recorded. 5-ileAII was incubated in commercial rabbit serum (Irvine Scientific; Santa Ana, CA) or Ringer's bicarbonate plus $5 \%$ vol/vol fetal calf serum (Pelfreez Biologicals; Rogers, AR) at $37^{\circ} \mathrm{C}$, or in Ringer's bicarbonate plus $6 \mathrm{~g} / 100 \mathrm{ml}$ bovine serum albumin (CRG-7, Armour Pharmaceutical Co., Kankakee, IL) at room temperature and at $37^{\circ} \mathrm{C}$.

Microperfusion-general experimental features. Normal rabbits on regular laboratory chow were used in all microperfusion experiments. The general methods of Burg and Orloff (18) and our modifications (15) of in vitro tubule perfusion have been previously described. Female New Zealand white rabbits between 1.5 and $2.5 \mathrm{~kg}$ were killed by de- capitation. The left kidney was quickly removed and decapsulated. Coronal slices 1-2 mm thick were cut and placed into Ringer's bicarbonate plus $6 \mathrm{~g} / 100 \mathrm{ml}$ albumin at $4^{\circ} \mathrm{C}$. Dissection was performed in the same chilled solution with the aid of a dissecting microscope. Proximal convoluted tubules were dissected from the deeper one-half of the cortex, usually from areas adjacent to an arcuate artery. Though the distinction between true surface convolutions and juxtamedullary convolutions is clear (15), that between midcortical and juxtamedullary convolutions is less so. Therefore, since not every tubule was from the deepest cortex, we have used the term "nonsurface" for our tubule population. Likewise, although about one-third of our tubules had a glomerulus attached by a neck region, no attempt was made to specifically dissect $S_{1}$ vs. $S_{2}$ segments.

After dissection, the tubules were transferred to a thermostatistically controlled chamber of $\cong 1 \mathrm{~cm}^{3}$ volume containing ports for constant infusion and removal of bath fluid, as well as for placement of Ringer's bicarbonate agarose bridges. The two ends of the tubule were sucked into glass holding-pipettes containing elastomeric silicone resin (Sylgard 184, Dow Corning Corp.; Midland, MI) at the tips, providing a water and electrical seal. The perfusion pipette, previously centered in one of the holding pipettes, was advanced into the tubule lumen, $50-100 \mu \mathrm{m}$. Perfusion rate was controlled hydrostatically. Transepithelial voltage $\left(V_{\mathrm{T}}\right)$ was measured continuously at the perfusion pipette via a Ringer's bicarbonate agarose bridge connected to a calomel electrode; a similar agarose bridge in the perfusion chamber, also connected to a calomel electrode, completed the circuit. $V_{\mathrm{T}}$ was measured with a battery-operated Keithley electrometer (model 602, Keithley Instruments Inc., Cleveland, $\mathrm{OH}$ ) and recorded on a strip-chart recorder (Rikadenki model B261, Soltec Corp.; Sun Valley, CA).

Timed collections of fluid from the tubule were made into a constantvolume pipette (CVP) under water-equilibrated mineral oil. Calibration of this pipette was performed daily as follows. At $37^{\circ} \mathrm{C}$, the perfusion pipette was advanced into a pipette containing a short $(\sim 200 \mu \mathrm{m})$ column of Sylgard at the tip and water-equilibrated mineral oil above the Sylgard. A bolus of perfusate was injected above the Sylgard into the oil, and the CVP was filled in triplicate from this perfusate.

Microperfusion-solutions. Solutions were synthetic ones designed to simulate rabbit serum and glomerular ultrafiltrate. Bath solution contained in millimolar: $\mathrm{Na}, 145 ; \mathrm{K}, 5 ; \mathrm{Cl}, 112 ; \mathrm{HCO}_{3}, 25 ; \mathrm{Ca}, 2.4 ; \mathrm{PO}_{4}$, $2.3 ; \mathrm{Mg}, 1.0 ; \mathrm{SO}_{4}, 1.0$; acetate, 10 ; glucose, 8 ; alanine, 5 . This solution also contained $6 \mathrm{~g} / 100 \mathrm{ml}$ defatted bovine serum albumin (CRG-7). The perfusate was an ultrafiltrate of the bath, prepared by pressure dialysis through Amincon PM-30 membranes (American Instrument Co., Silver Springs, MD). Baths were bubbled at $37^{\circ} \mathrm{C}$ with $95 \% \mathrm{O}_{2} /$ $5 \% \mathrm{CO}_{2}$ to $\mathrm{pH} 7.40$, drawn anaerobically into syringes, and pumped through the perfusion chamber at $\geqq 0.6 \mathrm{~cm}^{3} / \mathrm{min}$. We have previously shown by on-line bath $\mathrm{pH}$ electrodes that this method produces extremely stable bath pH (22). Perfusate was equilibrated with $95 \% \mathrm{O}_{2} / 5 \% \mathrm{CO}_{2}$ at $37^{\circ} \mathrm{C}$, and ${ }^{3} \mathrm{H}$-inulin was added (see below). Osmolality of bath and perfusate were matched at 295 mosM with small additions of water or $\mathrm{NaCl}$.

Microperfusion-net volume flux $\left(J_{v}\right)$ measurements. $\mathrm{J}_{\mathrm{v}}$ was measured using perfusate methoxy ${ }^{3} \mathrm{H}$-inulin (New England Nuclear, Boston, MA) exhaustively dialyzed by the method of Schafer et al. (23). $\mathrm{J}_{\mathrm{v}}$ was calculated from the equation: $\mathrm{J}_{\mathrm{v}}=V_{\mathrm{i}}-V_{0} / L$, where $V_{\mathrm{i}}$ is the perfusion rate in nanoliters per minute, $V_{0}$ is the collection rate in nanoliters per minute, and $L$ is the tubule length in millimeters. $V_{0}$ was measured directly, and $V_{\mathrm{i}}$ was calculated from $V_{0}=\mathrm{cpm}_{\mathrm{o}} / \mathrm{cpm}_{\mathrm{i}}$, where $\mathrm{cpm}_{\mathrm{o}}$ and $\mathrm{cpm}_{\mathrm{i}}$ are ${ }^{3} \mathrm{H}$ counts per minute per nanoliter of collected and perfused fluid, 
respectively. $L$ was measured directly by eyepiece micrometer. Care was taken to maximize sensitivity and precision of $\mathrm{J}_{\mathrm{v}}$ measurements. ${ }^{2}$

Microperfusion-experimental protocol. The general protocol was the same in all experiments. After being hooked up to the pipettes, the tubule was warmed to $37^{\circ} \mathrm{C}$ and allowed to equilibrate for $30 \mathrm{~min}$. During this and all subsequent periods the bath contained $1 \% \mathrm{vol} / \mathrm{vol}$ AII vehicle: Tris, $50 \mathrm{mM}$; glycine, $100 \mathrm{mM}, \mathrm{BSA}, 0.2 \mathrm{~g} / 100 \mathrm{ml}, \mathrm{pH}$ 5.0. This vehicle did not measurably change the bath $\mathrm{pH}$ or osmolality. After the equilibration period, control period collections were made (see below).

The continuously flowing bath was then changed to contain 5-ileAII, the 5-position moiety thought to be normally circulating in the rabbit (24), and/or saralasin. Synthetic 5-ile-AII or saralasin (Beckman Instruments, Inc.) was dissolved in the vehicle described above, aliquoted, and frozen until just before serial dilution and addition to the bath. Fresh stock solution was made frequently. $30 \mathrm{~min}$ after exposure of the tubule to AII a second group of collections was made. In some experiments done with AII at $10^{-11} \mathrm{M}$, bath remaining in the infusion syringe at the end of the experimental period was assayed for AII concentration by RIA as described above. The concentration at $10^{-11} \mathrm{M}$ should be $10.4 \mathrm{pg} / \mathrm{ml}$. Measured values were $11.78 \pm 0.62(\mathrm{SEM}) \mathrm{pg} / \mathrm{ml}(n=5)$, demonstrating presence of AII in the bath at the desired concentration. All experiments except those with AII plus saralasin contained a third (recovery) period in which the bath again contained only vehicle. 30 min after beginning this period, a final set of collections was made. Five collections were made per period.

Statistics. For any given tubule the means of four to five collections per period were used as values for that tubule. The group means for the control, experimental, and recovery periods were then computed using each tubule mean. In addition, to avoid loss of statistical power due to variability of control $J_{v}$ values, the experimental and recovery tubule means were also calculated as percent changes from the control

2. For a given experimental perturbation, the minimum increment or decrement of $\mathrm{J}_{\mathrm{v}}$ that can be detected is a function of the precision with which the CVP is filled, and the counting accuracy, a square-root function of the total counts. In turn, total counts are determined by perfusate counts per nanoliter, tubule length, $J_{v}$, perfusion rate, CVP volume, and total time the collected fluid is counted. With regard to precision of filling the CVP, triplicate calibrations performed daily had a total range around the mean of $\pm 0.5 \%$. During an experiment, collections for any given experimental period were made in quintuplicate to minimize sampling error. With regard to counting accuracy, the following mean values apply to these experiments: tubule length, $1.28 \mathrm{~mm}$; perfusate ${ }^{3} \mathrm{H}$ counts, $61.9 \mathrm{cpm} / \mathrm{nl}$; CVP, $160 \mathrm{nl} ; J_{v}, 0.747 \mathrm{nl} / \mathrm{mm}$ per min; $V_{i}$, $12.1 \mathrm{nl} / \mathrm{min}$. All samples were counted for $10 \mathrm{~min}$ in a Tracor model 6892 liquid scintillation counter (Tracor Analytic; Atlanta, GA). Thus, under these circumstances, the total mean counts for one collection are $108,570 \pm 329$, or $\pm 0.30 \%$. Using the formula above for $J_{v}$ and the mean values given, a $0.30 \%$ variation in collected counts would appear as a variation in $\mathrm{J}_{\mathrm{v}}$ of $\pm 0.026 \mathrm{nl} / \mathrm{mm}$ per min, i.e., the mean detectable change in $\mathrm{J}_{\mathrm{v}}$ above counting "noise" is $0.026 \mathrm{nl} / \mathrm{mm}$ per min, assuming $0 \%$ variability in filling of the CVP. Even by assuming worst-case additive random errors, i.e., scintillation counting at the upper end of the variation range plus overfilling the CVP by $0.5 \%$, with both occurring only during the experimental period, the mean minimal detectable change in $\mathrm{J}_{\mathrm{v}}$ rises to $0.069 \mathrm{nl} / \mathrm{mm}$ per min, still smaller than the smallest mean change seen with AII in these experiments. tubule means. Student's two-tailed $t$ test for paired samples was used for mean values derived from the same tubule; the $t$ test for unpaired samples was used for mean values from different tubules. Differences were considered significant if $P<0.05$. Other values such as tubule length, $V_{\mathrm{T}}$, and perfusion rate are expressed as mean $\pm \mathrm{SEM}$.

\section{Results}

Circulating plasma AII levels. Plasma AII concentration was measured by RIA in the rabbit as a rough approximation of renal cortical values. As shown in Fig. 1, the mixed arteriovenous plasma AII concentration of normal rabbits was $18.5 \pm 4 \mathrm{pg} / \mathrm{ml}$. This value rises with maneuvers stimulating renal sodium retention, i.e., diuretic- and-diet-induced sodium depletion and adrenalectomy, to $30.4 \pm 4 \mathrm{pg} / \mathrm{nl}$ and $43.7 \pm 10 \mathrm{pg} / \mathrm{ml}$, respectively ( $P<0.05$ normal vs. adrenalectomy). These values translate into molarities of $\sim 2 \times 10^{-11} \mathrm{M}$ for normals and $\leqq 5 \times 10^{-11}$ $\mathbf{M}$ for adrenalectomized rabbits.

Stability of AII in various isolated tubule baths. To insure the presence of AII at desired concentrations in the bath throughout the experiment, the stability of synthetic AII was examined by bioassay following incubation in three standard microperfusion baths. As shown in Fig. 2, rapid loss of bioactivity occurred in commercial rabbit serum, with a $t_{1 / 2}$ of $\sim 10 \mathrm{~min}$. Likewise, the addition of 5\% vol/vol fetal calf serum to Ringer's solution led to a loss of $\sim 50 \%$ of initial activity. On the contrary, incubation in Ringer's solution plus $6 \mathrm{~g} / 100 \mathrm{ml}$ albumin led to a very slight loss of activity at $37^{\circ} \mathrm{C}$, the temperature in the perfusion chamber, and to no loss of activity at $23^{\circ} \mathrm{C}$, the temperature of the infusion syringe containing bath plus hormone. Ringer's bicarbonate plus albumin was therefore used in all microperfusion experiments.

Response of $J_{v}$ to physiological doses of $A I I$. In all microperfusion experiments, AII was added to the bath only, since this is the most likely site for a control function of AII on the proximal tubule (25), and because luminal AII has been shown

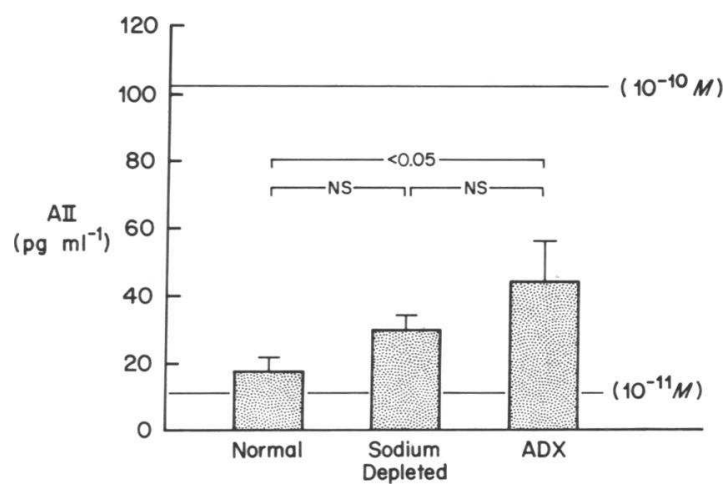

Figure 1. Mixed arteriovenous plasma AII levels measured by RIA in normal rabbits, rabbits given furosemide and a low-sodium diet, and adrenalectomized (ADX) rabbits. $n=6$ for each group. 


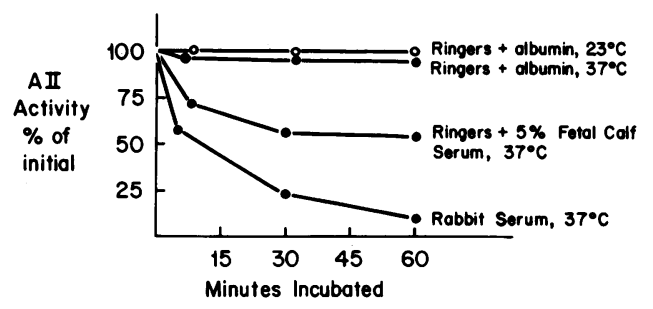

Figure 2. Stability of AII in three standard microperfusion baths. Each point represents the mean of two determinations, which varied by $<6 \%$. The open circles represent the incubation conditions which predominated during the microperfusion experiments, i.e., AII remained in a syringe in Ringer's plus albumin at $23^{\circ} \mathrm{C}$ until the moment it entered the perfusion chamber, when it was warmed to $37^{\circ} \mathrm{C}$.

to be rapidly hydrolyzed to small peptide fragments in this segment (26). As shown in Fig. 3, 10 $0^{-11} \mathrm{M}$ AII added to the bath in eight tubules increased $J_{v}$ in each case. The mean $J_{v}$ for control, AII, and recovery periods was $0.666 \pm 0.07,0.767 \pm 0.08$, and $0.695 \pm 0.08 \mathrm{nl} / \mathrm{mm}$ per min. This rise in $J_{v}$ was significant at $P<0.01$. When expressed as a percentage of the control period value, $J_{v}$ rose by a mean of $16 \%$ with $10^{-11} \mathrm{M}$ bath AII. Although the AII period $J_{v}$ was not significantly different from that of the recovery period, it was significantly different $(P<0.05)$ from the combined control and recovery period $J_{v}$ 's. Mean length of tubules was $1.20 \pm 0.07 \mathrm{~mm}$, and mean control period $V_{\mathrm{T}}$ (lumen negative) was $-4.6 \pm 0.5 \mathrm{mV}$. Perfusion rates for three consecutive periods were comparable at $12.01 \pm 0.25,12.78 \pm 0.42$, and $11.93 \pm 0.38 \mathrm{nl} / \mathrm{min}$, respectively.

When $10^{-10} \mathrm{M}$ AII was added to the bath, a smaller increase in $\mathrm{J}_{\mathrm{v}}$ was seen. As shown in Fig. 4, AII caused $\mathrm{J}_{\mathrm{v}}$ to rise in seven tubules and to fall slightly in two tubules. Mean $J_{v}$ 's were

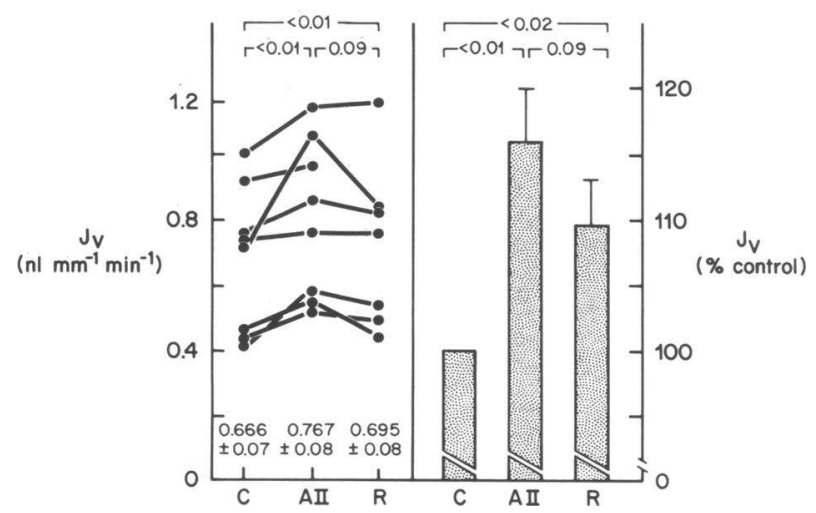

Figure 3. Effect of $10^{-11} \mathrm{M}$ bath AII on proximal convoluted tubule $\mathrm{J}_{\mathrm{v}}$. (Left) Values for individual tubules during control (C), AII, and recovery (R) periods. Mean $J_{v} \pm$ SEM for each period is shown. (Right) Mean ( \pm SEM) percentage changes, calculated from each tubule's percent change with AII and during recovery $(R)$ compared with its own control value.

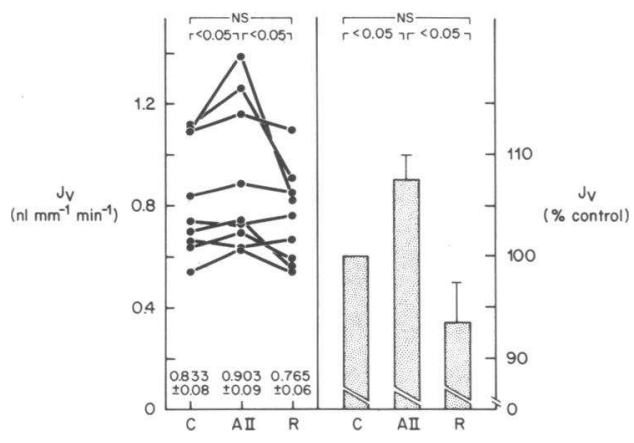

Figure 4. Effect of $10^{-10} \mathrm{M}$ bath AII on proximal convoluted tubule $\mathrm{J}_{\mathrm{v}}$. See Fig. 3 for symbols and format.

$0.833 \pm 0.08,0.903 \pm 0.09$, and $0.765 \pm 0.06 \mathrm{nl} / \mathrm{mm}$ per $\mathrm{min}$ for the control, AII, and recovery periods, respectively. Both the $\mathrm{J}_{\mathrm{v}}$ increase with AII and the recovery to control values were significant $(P<.05)$. Expressed as a percentage of control $\mathrm{J}_{\mathrm{v}}$, AII at $10^{-10} \mathrm{M}$ caused a $7.5 \%$ increase in $\mathrm{J}_{\mathrm{v}}$. For this group, mean tubule length was $1.38 \pm 0.17 \mathrm{~mm}$, mean $V_{\mathrm{T}}$ was $-4.7 \pm 0.3$ $\mathrm{mV}$; and mean perfusion rates for control, AII, and recovery periods were $11.49 \pm 0.44,11.63 \pm 0.33$, and $11.98 \pm 0.35 \mathrm{nl} / \mathrm{min}$.

A comparison of the effect of $10^{-11}$ vs. $10^{-10} \mathrm{M}$ shows no significant difference when the absolute increments in $\mathrm{J}_{\mathrm{v}}$ 's by each dose are compared $(+0.101 \pm 0.03$ vs. $+0.070 \pm 0.03 \mathrm{nl} / \mathrm{mm}$ per min, NS). However, when the percentage increases are examined the two groups are statistically different $(+16 \% \pm 4 \%$ vs. $+7.5 \% \pm 2.5 \%, P<0.05)$.

Effect of high-dose AII on $J_{v}$. Although the AII doses of $10^{-11}$ to $10^{-10} \mathrm{M}$ are probably close to the physiologic peritubular concentration in vivo, previous investigators have demonstrated an inhibitory effect on proximal tubule sodium transport at doses of $\sim 10^{-7}-10^{-6} \mathrm{M}$. To confirm these possibly pharmacologic effects, $10^{-7} \mathrm{M}$ AII was examined. Fig. 5 shows that this dose inhibited $\mathrm{J}_{\mathrm{v}}$ by $24 \%$ ( $P<0.05$ from AII period), with complete recovery. $J_{v}$ values for control, AII, and recovery periods were $0.877 \pm 0.17,0.674 \pm 0.17$, and $0.797 \pm 0.19 \mathrm{nl} / \mathrm{mm}$ per

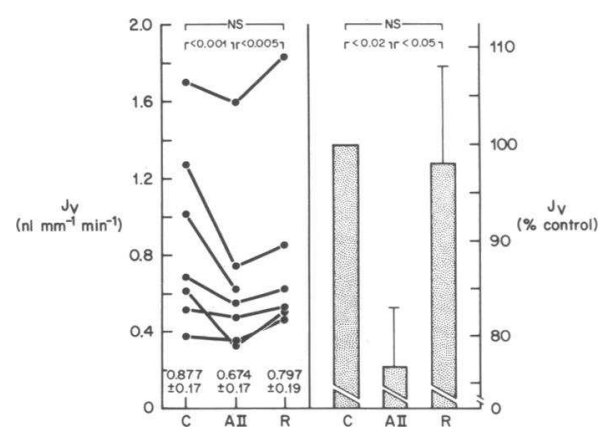

Figure 5. Effect of $10^{-7} \mathrm{M}$ bath All on proximal convoluted tubule $\mathrm{J}_{\mathrm{v}}$. See Fig. 3 for symbols and format. 
min. Mean tubule length was $1.26 \pm 0.21 \mathrm{~mm}$, and mean control period $V_{\mathrm{T}}$ was $-4.6 \pm 0.4 \mathrm{mV}$. Perfusion rates for the three periods were $11.38 \pm 0.28,11.65 \pm 0.36$, and $11.55 \pm 0.43 \mathrm{nl} / \mathrm{min}$.

Time controls. To insure that either increases or decreases in $\mathrm{J}_{\mathrm{v}}$ during the middle phase of these lengthy $(6 \mathrm{~h})$ experiments were not due to a natural variation with time, five tubules were handled in an identical fashion to the previous experimental tubules, except that no AII was added during the second period. $\mathrm{J}_{\mathrm{v}}$ did not change significantly during any period of these studies $(0.683 \pm 0.14,0.684 \pm 0.14$, and $0.661 \pm 0.12 \mathrm{nl} / \mathrm{mm}$ per $\mathrm{min}$, all NS). Perfusion rates for these three periods were $12.75 \pm 0.37$, $12.88 \pm 0.38$, and $12.67 \pm 0.40 \mathrm{nl} / \mathrm{min}$ ). Thus, the increases in $\mathrm{J}_{\mathrm{v}}$ with $10^{-11}$ and $10^{-10} \mathrm{M}$, and the decrease with $10^{-7} \mathrm{M}$ AII, cannot be attributed to spontaneous variation.

Effects of saralasin on $J_{v}$. A number of micropuncture studies have utilized the AII blocker saralasin to examine the role of AII in proximal tubule reabsorption (27-29). These have been predicated on the concept that, as in vascular beds, saralasin acts as a nearly pure antagonist with little, if any, intrinsic agonistic action. However, in superficial proximal convoluted tubules, some studies have suggested that saralasin is agonistic at $10^{-8} \mathrm{M}(30)$ and at $10^{-7} \mathrm{M}(12)$. In the jejunum, Levens et al. (31) found saralasin agonistic at both low and high doses. Saralasin was therefore examined for intrinsic agonistic activity in rabbit nonsurface proximal convoluted tubules.

An attempt was made to mimic in vitro the peritubular saralasin concentrations that would prevail in vivo in the micropuncture studies cited above (27-29). Pharmacokinetic data on saralasin plasma levels at various systemic infusion rates were taken from a study by Pettinger et al. (32) and plotted as a linear regression in Fig. 6. The systemic saralasin infusion rates used in references 27 and 29 are shown to result in a predicted plasma saralasin concentration of $\sim 10^{-7} \mathrm{M}$. Therefore, since there is no intrarenal generation of saralasin, this value was used as the likely peritubular concentration. Shown in Fig.

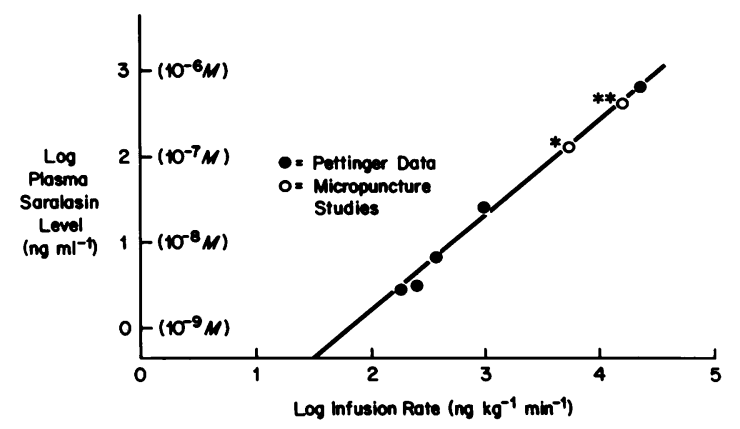

Figure 6. Plasma saralasin concentrations as a function of infusion rate. Closed circles and the regression line are from data of reference 32. Two micropuncture studies using saralasin infusion (open circles, *, reference $27 ; *$, reference 29 ) result in predicted plasma saralasin concentrations of $\sim 10^{-7}$ M. $y=1.05 x-1.8 . r=0.988$. $P<0.01$.

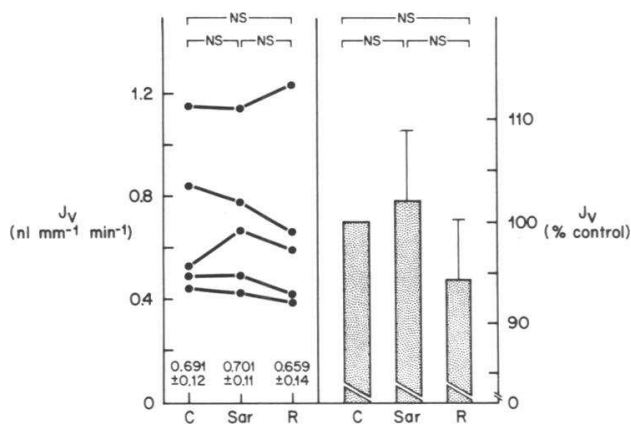

Figure 7. Effect of $10^{-7} \mathrm{M}$ bath saralasin on proximal convoluted tubule $J_{v}$. See Fig. 3 for format. Sar, saralasin, $R$, recovery.

7 is the effect of $10^{-7} \mathrm{M}$ bath saralasin on $\mathrm{J}_{\mathrm{v}}$ in five tubules. Mean $\mathrm{J}_{\mathrm{v}}$ 's for control, saralasin, and recovery periods were $0.691 \pm 0.12,0.701 \pm 0.11$, and $0.659 \pm 0.14 \mathrm{nl} / \mathrm{mm}$ per $\mathrm{min}$, respectively (NS control vs. experimental vs. recovery). For this group of tubules, mean length was $1.28 \pm 0.12 \mathrm{~mm}$ and mean $V_{\mathrm{T}}$ was $-6.0 \pm 0.28 \mathrm{mV}$. Perfusion rates for the three periods were $13.41 \pm 0.62,13.28 \pm 0.70$, and $13.33 \pm 0.54 \mathrm{nl} / \mathrm{min}$. Thus, at peritubular concentrations likely to prevail during infusion studies, saralasin has no direct intrinsic agonistic effect on $\mathbf{J}_{\mathbf{v}}$.

Effects of saralasin plus AII. In five tubules, both saralasin at $10^{-7} \mathrm{M}$ plus AII at $10^{-11} \mathrm{M}$ were added in concert. This in vitro experiment thus approximated the in vivo saralasin studies previously cited. As shown in Fig. 8, saralasin, at this peritubular concentration, completely blocked the stimulatory effect of $10^{-11}$ $M$ AII. The $J_{v}$ 's for control and saralasin-plus-AII periods were $0.65 \pm 0.05$ and $0.61 \pm 0.10 \mathrm{nl} / \mathrm{mm}$ per min (NS). The perfusion rates were $10.19 \pm 0.67$ and $10.41 \pm 0.62 \mathrm{nl} / \mathrm{mm}$ per $\mathrm{min}$, respectively.

AII effect on $V_{T}$. In our laboratory, proximal tubules meeting morphological criteria for experimentation tend to have an increase in lumen-negative $V_{T}$ throughout the experiment. This increase in $V_{\mathrm{T}}$ is relatively rapid for $\sim 1-2 \mathrm{~h}$ and then appears

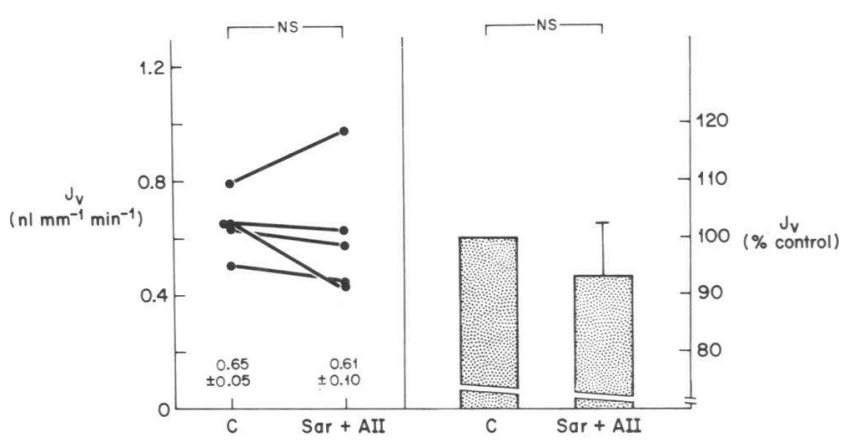

Figure 8. Effect of $10^{-7} \mathrm{M}$ bath saralasin plus $10^{-11} \mathrm{M}$ AII on proximal convoluted tubule $J_{v}$. See Fig. 3 for format. 
to approach an asymptote. Fig. 9 shows $V_{\mathrm{T}}$ vs. time in two representative AII experiments. As shown, neither high-dose $\left(10^{-7} \mathrm{M}\right)$ nor low-dose $\left(10^{-10} \mathrm{M}\right) \mathrm{AII}$, which had opposite effects on $\mathrm{J}_{\mathrm{v}}$, noticeably altered $V_{\mathrm{T}}$. Likewise, the rate of rise of $V_{\mathrm{T}}$, i.e., the slope of this curve, did not change upon addition of AII, nor were the slopes different in the time controls compared with AII experiments (data not shown). Therefore, both stimulatory and inhibitory effects of AII on $J_{v}$ appeared to be electroneutral.

\section{Discussion}

These studies are important in that they: $(a)$ demonstrate a direct effect of AII on the proximal convoluted tubule in vitro under open-lumen transport conditions, $(b)$ show AII effects on nonsurface proximal tubules, $(c)$ directly measure transepithelial voltage in the proximal tubule during AII administration, demonstrating that the transport effect of AII is not associated with a measurable change in transepithelial voltage, and $(d)$ measure plasma AII levels in rabbits by RIA. Our data also confirm the biphasic dose-response pattern seen in other studies.

Three major aspects of our studies deserve particular attention: the directness, magnitude, and mechanism of the AII effect.

Studies examining a possible direct effect of AII on epithelial transport have been complicated by interactions with the sympathetic nervous system. Angiotensin's ability to enhance norepinephrine release from sympathetic nerve endings is well known (16). Indeed, the stimulation of jejunal volume reabsorption by low doses of AII appears due solely to the release of norepinephrine (33), whereas the effects on colonic transport persist after denervation (2). In the kidney, the initial clearance

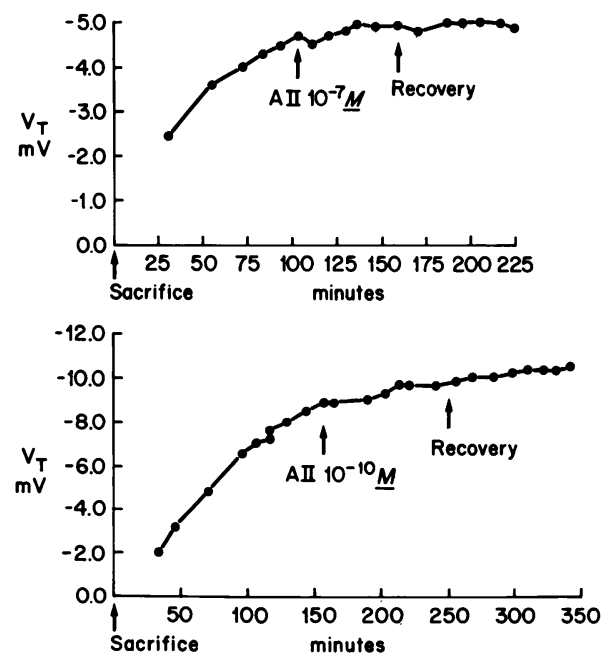

Figure 9. $V_{\mathrm{T}}$ (lumen negative) vs. time in two representative experiments. Addition of both AII at $10^{-7} \mathrm{M}$ (top) or $10^{-10} \mathrm{M}$ (bottom) had no discernible effect on $V_{T}$. studies by McGiff (34) suggested that blockade of the sympathetic nervous system ablated the antinatriuretic effect of low-dose AII infusion. However, subsequent clearance studies by Waugh (35) and proximal tubule micropuncture studies by Pelayo and Blantz (36) have suggested an antinatriuretic effect of exogenous or endogenous AII that is independent of catecholamine release. Our studies, in which adrenergic nerve endings on tubular basement membranes have been removed during the dissection process, show a direct effect of peritubular AII on proximal tubule $\mathbf{J}_{\mathbf{v}}$. Such a direct effect is most likely mediated by hormonereceptor binding.

Receptors for AII have been shown on both brush border and basolateral membranes of (primarily proximal) tubule suspensions $(30,37)$. Although the precise function of each set of receptors remains to be determined, current evidence suggests that luminal AII undergoes rapid hydrolysis with tubular uptake of fragments (26), whereas basolateral AII produces changes in epithelial transport $(12,13)$. Presumably, basolateral AII receptors mediate this latter effect. The dissociation constants for these basolateral receptors are consistent with the transport responses at hormonal concentrations in the $10^{-11}-10^{-10} \mathrm{M}$ range which we have demonstrated. Moreover, this concentration range is probably physiologic, since our measured plasma AII values range from $2 \times 10^{-11}$ in sodium-replete rabbits to $\sim 5 \times 10^{-11}$ $M$ in adrenalectomized rabbits.

The magnitude of $J_{v}$ changes demonstrated here compare well with the findings of others: Spinelli and Walther (12) found stimulation of $\mathrm{J}_{\mathrm{v}}$ by $17 \%$ at $10^{-10} \mathrm{M}$ peritubular AII, comparable to our $16 \%$ at $10^{-11} \mathrm{M}$. Also, our $24 \%$ inhibition at $10^{-7} \mathrm{M}$ agrees with Steven's $23 \%$ at $2 \times 10^{-8} \mathrm{M}$ (13). Our results in nonsurface convolutions are thus similar to those of rat superficial convolutions. The physiological significance to the organism of the high-dose inhibition is uncertain, as there is little evidence that peritubular AII concentrations reach these levels in vivo. Moreover, inhibition of proximal reabsorption is often not reflected in the final urine, owing to compensatory reabsorption by the loop of Henle and distal nephron segments. On the other hand, even small increases in proximal reabsorption are reflected in the final urine and in overall volume status. For example, in the human with a glomerular filtration rate of 180 liters/24 $\mathrm{h}$ and a fractional proximal reabsorption of $60 \%$, a sustained $16 \%$ increase in $\mathrm{J}_{\mathrm{v}}$ would result in the addition of more than 17 liters of reabsorbate per $24 \mathrm{~h}$ to the extracellular space in the absence of other compensatory changes. Moreover, it is likely that the magnitude of stimulation demonstrated here represents a minimal effect of AII. Studies using AII blockade with saralasin or angiotensin converting enzyme inhibition have shown larger effects of endogenous AII on proximal reabsorption in states associated with high circulating AII levels compared with control states $(27,38)$. It is not clear if this change in AII effect represents a change in tubule responsiveness to AII or some other intrarenal action of AII. Our normal rabbits are on a relatively high-sodium diet. We therefore attempted to examine the effects of AII on tubules harvested from sodium-depleted 
rabbits. However, these proximal convoluted tubules were extremely friable upon dissection, and no tubules of sufficient viability for these experiments were obtained. No attempts were made at perfusing convolutions from adrenalectomized rabbits.

We examined the competitive AII antagonist saralasin. Some data have suggested that the action of saralasin in relationship to AII is different in epithelial as opposed to vascular tissues. In the rat jejunum, saralasin is agonistic at all doses. It does not antagonize the stimulatory effects of low-dose AII, and it blocks the inhibitory effect of high-dose AII, allowing the latter to be stimulatory (31). In renal tubules, saralasin alone has been reported to be stimulatory at $10^{-7} \mathrm{M}$ (12) and at $10^{-9} \mathrm{M}$ (30). We addressed this issue by first examining saralasin alone at a dose $\left(10^{-7} \mathrm{M}\right)$ which probably prevailed in micropuncture experiments using saralasin infusions, and found no significant agonistic activity. In addition, this dose prevented the rise in $J_{v}$ seen with $10^{-11} \mathrm{M}$ AII. These experiments are thus consistent with an action of saralasin on the proximal tubule as an AII receptor antagonist only. It is possible, however, that other saralasin-AII dose combinations could yield other results.

The action of AII on the proximal convolution appears to involve an electroneutral transport process(es), at least as assessed by $V_{\mathrm{T}}$. This is characteristic of AII's action in other epithelia, i.e., colon, (4), jejunum (3), and gallbladder (39). In the proximal tubule, Harris and Young (13) indirectly assessed $V_{\mathrm{T}}$ by measuring chloride distribution across the epithelium. Although they found no effect of AII on $V_{\mathrm{T}}$, their method is based on the assumption that all chloride movement is passive and paracellular. However, recent evidence has suggested that at least a portion of chloride movement may be transcellular and coupled to sodium entry (40), therefore challenging the validity of this method. Our studies directly measured $V_{\mathrm{T}}$ at the lumen pipette and found no measurable change with AII at doses that either stimulated or inhibited $J_{v}$. It is, of course, possible that the relatively small changes in $J_{v}(0.100 \mathrm{nl} / \mathrm{mm}$ per min $)$ induced by AII were associated with proportionately small changes in $V_{\mathrm{T}}$ which went undetected. The relationship between $\mathrm{J}_{\mathrm{v}}$ driven by electrogenic processes (i.e., coupled organic solute co-transport) and the contribution of these processes to $V_{\mathrm{T}}$ have not been systematically examined. Extrapolation from several available studies $(15,41,42)$ suggests that electrogenic processes produce changes in $V_{\mathrm{T}}$ of $0.3-1.2 \mathrm{mV}$ per $0.100 \mathrm{nl} / \mathrm{mm}$ per min change in $J_{v}$. Our system should be able to detect changes of this magnitude. The larger changes in $\mathrm{J}_{\mathrm{v}}$ produced by highdose AII probably should have produced detectable changes in $V_{\mathrm{T}}$. We did not observe such changes. However, the transport process(es) inhibited by high-dose AII may not be the same one(s) stimulated by physiologic concentrations. In any event, further experiments with AII involving omission of luminal organics are required to be confident that the AII effect is electroneutral.

The intracellular mechanism of $\mathrm{J}_{\mathrm{v}}$ stimulation at low doses and inhibition at high doses remains speculative. Many peptide hormones appear to alter transport via effects on cyclic AMP.
Available evidence, however, suggests that AII does not raise, and may even lower, cyclic AMP levels in renal cortex (4346). Since cyclic AMP inhibits $J_{v}$ in the proximal tubule (47), a fall in cyclic AMP might stimulate $\mathrm{J}_{\mathrm{v}}$. On the other hand, changes in cytosolic calcium activity, a mediator of AII action in many tissues, might produce the effects seen here. Although some studies have shown inhibition of $\mathrm{J}_{\mathrm{v}}$ in the proximal tubule with maneuvers thought to increase cytosolic calcium (48), others have shown enhanced $J_{v}(49)$. Moreover, sodium entry into cultured epithelial cells is enhanced when cytosolic calcium is moderately raised. However, when calcium loading is extended still further, stimulation of sodium entry falls below the peak value (50). It is therefore possible that progressively larger increases in cytosolic calcium, due to AII, might produce the biphasic dose response. The stimulation of transport might be mediated through cyclic AMP-independent protein phosphorylation, as has been shown to occur in the hepatocyte (1). The inhibitory effect might be a direct action of calcium per se on sodium transport (48), or could be due to stimulation of prostaglandin synthesis by calcium, though the evidence for a significant role of prostaglandins in the proximal tubule is poor (51). The role of cytosolic calcium in the action of any hormone on renal tubules, and of AII in particular, remains poorly understood.

\section{Acknowledgments}

The authors wish to thank Ms. Susan Corona and Ms. Amy Womack for expert technical assistance, Ms. Cathrine Schmid for typing the manuscript, Dr. Billy Arant for the angiotensin-by-RIA determinations, and Dr. William Campbell for assistance with the AII bioassay.

This work was supported by National Institutes of Health (NIH) Research grants 5-R01-AM-23901, 5-R01-AM-14677, and NIH Training grant 5-T32-AM-07257.

\section{References}

1. Peach, M. J. 1981. Molecular actions of angiotensin. Biochem. Pharmacol. 30(20):2745-2751.

2. Davies, N. T., K. A. Munday, and B. J. Parsons. 1970. The effect of angiotensin on rat intestinal fluid transfer. J. Endocrinol. 48:39-46.

3. Bolton, J. E., K. A. Munday, B. J. Parsons, and B. G. York. 1975. Effects of angiotensin II on fluid transport, transmural potential difference and blood flow by rat jejunum in vivo. J. Physiol. (Lond.). 253:411428.

4. Levens, N. R., M. J. Peach, R. M. Carey, J. A. Poat, and K. A. Munday. 1981. Changes in an electroneutral transport process mediated by angiotensin II in the rat distal colon in-vivo. Endocrinology. 108(4):1497-1504.

5. Hornych, A., P. Meyer, and P. Milliez. 1973. Angiotensin, vasopressin, and cyclic AMP: Effects on sodium and water fluxes in rat colon. Am. J. Physiol. 224(5):1223-1229.

6. Hughes-Jones, N. C., G. W. Pickering, P. H. Sanderson, H. Scarborough, and J. Vandenbrouckey. 1949. The nature of the action of renin and hypertensin on renal function in the rabbit. J. Physiol. (Lond.). 109:288-307. 
7. Navar, L. G., and H. G. Langford. 1974. Effects of angiotensin on the renal circulation. In Handbuch der experimentellen Pharmakologie Angiotensin, Irvine H. Page and F. Meslin Bumpus, editors, SpringerVerlag, New York. 37:455-474.

8. Horster, M., W. Nagel, J. Schnermann, and K. Thurau. 1966. Zur Frage einer direkten Angiotensinwirkung auf die Natrium-resorption im proximalen Tubulus und in der Henleschen Schleife der Rattenniere. Pflügers Arch. 292:118-128.

9. Lowitz, H. D., K. O. Stumpe, and B. Ochwadt. 1969. Micropuncture study of the action of angiotensin-II on tubular sodium and water reabsorption in the rat. Nephron. 6:174-187.

10. Myers, B. D., W. M. Deen, and B. M. Brenner. 1975. Effects of norepinephrine and angiotensin II on the determinants of glomerular ultrafiltration and proximal tubule fluid reabsorption in the rat. Circ. Res. 37:101-110.

11. Steven, K. 1974. Effect of peritubular infusion of angiotensin II on rat proximal nephron function. Kidney Int. 6:73-80.

12. Spinelli, F., and A. Walther. 1978. Biphasic tubular effect of angiotensin II and $\mathrm{Sar}^{1} \mathrm{Ala}^{8}$ on net water and sodium reabsorption in the proximal tubule of the rat kidney. Kidney Int. 13:532. (Abstr.)

13. Harris, P. J., and J. A. Young. 1977. Dose-dependent stimulation and inhibition of proximal tubular sodium reabsorption by angiotensin II in the rat kidney. Pflügers Arch. 367:295-297.

14. Flamenbaum, W., and R. J. Hamburger. 1974. Superficial and deep juxtaglomerular apparatus renin activity of the rat kidney. J. Clin. Invest. 54:1373-1381.

15. Jacobson, H. R. 1979. Characteristics of volume reabsorption in rabbit superficial and juxtamedullary proximal convoluted tubules. J. Clin. Invest. 63(3):410-418.

16. Lifschitz, M. D., and J. H. Stein. 1981. Renal vasoactive hormones. In The Kidney. B. M. Brenner and F. C. Rector, editors. Second Ed. W.B. Saunders Co., Philadelphia. 1:650-720.

17. Jensen, P. K., and K. Steven. 1977. Angiotensin II induced reduction of peritubular capillary diameter in the rat kidney. Pflügers Arch. 371:245-250.

18. Burg, M. B., and J. Orloff. 1968. Control of fluid absorption in the renal proximal tubule. J. Clin. Invest. 47:2016-2024.

19. Arant, B. S., Jr., and W. H. Stephenson. 1982. Developmental changes in cardiac output and peripheral resistance compared with arterial plasma concentrations of prostaglandins and angiotensin II in conscious dogs. Fed. Proc. 41:1544. (Abstr.)

20. Wingo, C. S., D. W. Seldin, J. P. Kokko, and H. R. Jacobson. 1982. Dietary modulation of active potassium secretion in the cortical collecting tubule of adrenalectomized rabbits. J. Clin. Invest. 70:579586.

21. Regoli, D., and J. R. Vane. 1964. A sensitive method for the assay of angiotensin. Br. J. Pharmacol. 23:351-359.

22. Jacobson, $\mathrm{H}$. R. 1981. Effects of $\mathrm{CO}_{2}$ and acetazolamide on bicarbonate and fluid transport in rabbit proximal tubules. Am. J. Physiol. 240(Renal Fluid Electrolyte Physiol 9):F54-F62.

23. Schafer, J. A., S. L. Troutman, and T. E. Andreoli. 1974. Volume reabsorption, transepithelial potential difference, and ionic permeability properties in mammalian superficial proximal straight tubules. J. Gen. Physiol. 64:582-607.

24. Nakajima, T., T. Nakayama, and H. Sokabe. 1971. Examination of angiotensin-like substances from renal and extrarenal sources of mammalian and nonmammalian species. Gen. Comp. Endocrin. 17:458466.
25. Burghardt, W., H. Schweisfurth, and H. Dalheim. 1982. Juxtaglomerular angiotensin II formation. Kidney Int. 22:(Suppl. 12):S49S54.

26. Peterson, D. R., G. Chrabaszca, W. R. Peterson, and S. Oparil. 1979. Mechanism for renal tubular handling of angiotensin. Am. J. Physiol. 236(Renal Fluid Electrolyte Physiol 5):F365-F372.

27. Steiner, R. W., B. J. Tucker, and R. C. Blantz. 1979. Glomerular hemodynamics in rats with chronic sodium depletion. J. Clin. Invest. 64:503-512.

28. Reineck, H. J., and R. Parma. 1982. Angiotensin II mediates avid proximal reabsorption in volume expanded animals with immediate aortic clamping. Kidney Int. 21:285. (Abstr.)

29. Ploth, D. W., and R. N. Roy. 1982. Renal and tubuloglomerular feedback effects of $\left[\mathrm{Sar}^{1}, \mathrm{Ala}^{8}\right]$ angiotensin II in the rat. Am. J. Physiol. 242(Renal Fluid Electrolyte Physiol 11):F149-F157.

30. Freelander, A. E., and T. L. Goodfriend. 1977. Angiotensin receptors and sodium transport in renal tubules. Fed. Proc. 36:481. (Abstr.)

31. Levens, N. R., M. J. Peach, R. M. Carey, J. A. Poat, and K. A. Munday. 1981. Response of rat jejunum to angiotensin II: role of norepinephrine and prostaglandins. Am. J. Physiol. 240(Gastrointest. Liver Physiol. 3):G17-G24.

32. Pettinger, W. A., K. Keeton, and K. Tanaka. 1975. Radioimmunoassay and pharmacokinetics of saralasin in the rat and hypertensive patients. Clin. Pharmacol. Ther. 17:146-158.

33. Levens, N. R., M. J. Peach, and R. M. Carey. 1981. Interactions between angiotensin peptides and the sympathetic nervous system mediating intestinal sodium and water absorption in the rat. J. Clin. Invest. 67:1197-1207.

34. McGiff, J. C. 1967. Natriuretic effect of angiotensin in dogs revealed after administration of reserpine and guanethidine. Circ. Res. 20:664-675.

35. Waugh, W. H. 1972. Angiogensin II. Local renal effects of physiological increments in concentration. Can. J. Physiol. Pharmacol. 50:711-716.

36. Pelayo, J. C., and R. C. Blantz. 1982. Interactions of angiotensin II and renal adrenergic nervous activity on glomerular hemodynamics and proximal fluid reabsorption. Clin. Res. 30:541A. (Abstr.)

37. Brown, G., and J. Douglas. 1983. Angiotensin II-binding sites in rat and primate isolated renal tubular basolateral membranes. Endocrinology. 112:2007-2014.

38. Huang, W. C., D. W. Ploth, and L. G. Navar. 1982. Angiotensin mediated alterations in nephron function in Goldblatt hypertensive rats. Am. J. Physiol. 243(Renal Fluid Electrolyte Physiol 12):F553-F560.

39. Leyssac, P. P., L. O. Kristensen, P. Christensen, and O. Frederiksen. 1974. The effect of angiotensin on isosmotic fluid absorption by the rabbit gall-bladder in-vitro. Acta Physiol. Scand. 92:508-516.

40. Warnock, D. G., and J. Eveloff. 1982. $\mathrm{NaCl}$ entry mechanisms in the luminal membrane of the renal tubule. Am. J. Physiol. 242(Renal Fluid Electrolyte Physiol 11):F561-F574.

41. Burg, M., C. Patlak, N. Green, and D. Villey. 1976. Organic solutes in fluid absorption by renal proximal convoluted tubules. Am. J. Physiol. 231:627-637.

42. Imai, M., D. W. Seldin, and J. P. Kokko. 1977. Effect of perfusion rate on the fluxes of water, sodium, chloride, and urea across the proximal convoluted tubule. Kidney Int. 11:18-27.

43. Munday, K. A., B. J. Parsons, J. A. Poat, G. A. D'Auriac, and P. Meyer. 1976. The role of cyclic $3^{\prime}-5^{\prime}$ adenosine monophosphate in 
the responses of the intestine and kidney to angiotensin. J. Endocrinol. 69:297-298.

44. Guder, W. G., and A. Repprecht. 1976. Hormonal regulation of gluconeogenesis in isolated rat kidney tubule fragments. In Use of Isolated Liver Cells and Kidney Tubules in Metabolic Studies, J. M. Tager, H. D. Söling, and J. R. Williamson, editors. North Holland Publishing Company, Amsterdam. 379-389.

45. Torres, V. E., T. E. Northrup, R. M. Edwards, S. V. Shah, and T. P. Dousa. 1978. Modulation of cyclic nucleotides in isolated rat glomeruli. J. Clin. Invest. 62:1334-1343.

46. Woodcock, E. A., and C. I. Johnston. 1982. Inhibition of adenylate cyclase by angiotensin II in rat renal cortex. Endocrinology. 111(5):16871691.

47. Jacobson, H. R. 1979. Altered permeability in the proximal tubule response to cyclic AMP. Am. J. Physiol. 236(Renal Fluid Electrolyte Physiol. 5):F71-F79.

48. Friedman, P. A., J. F. Figueiredo, T. Maack, and E. E. Windhager. 1981. Sodium-calcium interactions in the renal proximal convoluted tubule of the rabbit. Am. J. Physiol. 240(Renal Fluid Electrolyte Physiol. 9):F558-F568.

49. McKeown, J. W. 1983. Effects of calcium ionophore A23187 on fluid and phosphate reabsorption in rabbit proximal convoluted tubules. Kidney Int. 23(1):106. (Abstr.)

50. Taub, M., and M. H. Saier, Jr. 1979. Regulation of ${ }^{22} \mathrm{Na}^{+}$transport by calcium in an established kidney epithelial cell line. J. Biol. Chem. 254(22):11440-11444.

51. Kokko, J. P. 1981. Effect of prostaglandins on renal epithelial electrolyte transport. Kidney Int. 19:791-796. 